\title{
Postur Kifosis Menyebabkan Gangguan Keseimbangan Statis Lansia
}

\author{
Rema Ira Prastiwi ${ }^{*}$, Riska Risty $\mathbf{W}^{2}$, Sri Lestari ${ }^{3}$ \\ ${ }^{1,2,3}$ Fakultas Ilmu Kesehatan, Universitas 'Aisyiyah Yogyakarta \\ *Email: remairaprastiwi98@gmail.com
}

\begin{abstract}
Background: Elderly is someone who has body functions deficiency both physically and psychologically. One of the physical function deficiencies is the decrease in musculoskeletal conditions that affects the balance of postural muscles which results in the changes of kyphosis posture, so that it affects the changes of the body's center of gravity (COG) toward the fulcrum which causes disturbance of static balance. This poor static balance creates the risk of falling which causes many problems and even death for the elderly. Aims of this study to determine the correlation between changes in kyphosis posture and static balance disorders in the elderly at the Posyandu (Integrated Healthcare Center) of Semaka area. Methods: This research was a descriptive correlation and cross-sectional approach. As for the number of respondent in this study were 60 erderly. Results: The results of the Kendall tau test obtained the value of 0.000 with a significant value of 0.389. This showed that the p value was $<0.05$, this Ha was accepted and Ho was rejected. This meant that there was a correlation between posture changes and static balance disorders in the elderly. Conclusion: There is a correlation between posture changes and the static balance in the elderly at the Posyandu of Semaka area. For health workers in the local health center area to carry out regular counseling on the risk of falling falls by correcting balance disorders in the ederly in order to preventive measures.
\end{abstract}

Keywords: kyphosis posture, static balance, elderly

\section{PENDAHULUAN}

Lanjut usia (Lansia) merupakan suatu proses akhir pada kehidupan manusia yang mengakibatkan kemampuan jaringan menurun secara perlahan untuk memperbaiki diri dan mempertahankan fungsi normalnya dan ini bersifat wajar (Nuraini, Haryanto, \& Fauzingtyas, 2017). Pada fase lansia terjadinya perubahan fisik, mental, sosial, dan kesehatan, ini menyebabkan kesulitan dalam melakukan ADL, penyakit degeneratif, penurunan kognitif, gangguan keseimbangan dan lainnya (Sari, 2016). Saat keseimbangan terganggu maka akan mempengaruhi aktifitas sehari-hari pada lansia karena tidak sanggup melakukan pekerjaan, sehingga akan berkurangnya aktifitas fisik dan ini juga akan menimbulkan kemunduran yang bersifat negatif (Ibrahim, Nurhasanah, \& Juanita2, 2018).

Keseimbangan statis merupakan
posisi tubuh yang mempertahankan posisi
seimbang dalam keadaan diam dan
merupakan awalan sebelum terjadinya
pergerakan. Buruknya keseimbangan
statis ini juga dipengaruhi karena
buruknya kemampuan otot postural dalam
menopang tubuh, perubahan kemampuan
tersebut akan berpengaruh dalam keadaan
postural menjaga keseimbangan statis
tubuh dalam bidang tumpu (Pristianto,
Adiputra, \& Irfan, 2016). Gangguan
keseimbangan postural ini dipengaruhi
oleh kelemahan otot ektremitas atas dan
bawah, stabilitas postural, maupun juga
gangguan secara fisiologis dari salah satu
indera yang ada dalam tubuh manusia,
faktor lain juga dapat disebabkan oleh
penuaan juga turut mempengaruhi
terjadinya gangguan keseimbangan
(Pramadita, Wati, Muhartomo, Kognitif,


\& Romberg, 2019). Dari faktor di atas berakibat pada perubahan bentuk tulang terutama bagian vertebra yang akan berkaitan pada postur tubuh salah satunya adalah perubahan postur tubuh kifosis.

Kifosis merupakan salah satu bentuk kelainan yang muncul pada tulang belakang manusia yang menyebabkan postur tubuh lansia membungkuk. Akibat perubahan ini menyebabkan salah satu resiko gangguan keseimbangan yaitu resiko jatuh. Lansia merupakan bagian umur yang paling tinggi mengalami resiko gangguan keseimbangan postural (Rudy \& Setyanto, 2019). Gangguan keseimbangan menyebabkan resiko jatuh pada lansia. Jatuh dapat memunculkan banyak sekali dampak buruk pada kesehatan lansia seperti luka pada kulit, patah tulang, gangguan mobilitas fisik bahkan kematian (Rudy \& Setyanto, 2019). Fisioterapi sebagai tenaga kesehatan sangat berperan penting dan harus memiliki kemampuan untuk memaksimalkan potensi gerak dan fungsi dalam lingkup promotif, preventif, kuratif, dan rehabilitatif. Hal ini menjadi bukti bahwa fisioterapi tidak hanya berperan dalam kuratif dan rehabilitatif saja namun juga berperan besar dalam preventif.

Menurut penelitian yang dilakukan Sulaiman and Anggriani 2018 dari 60 lansia dengan postur kifosis $85 \%$ memiliki keseimbangan statis yang buruk, akibat perubahan tulang belakang yang menjadi bungkuk sehingga mengakibatkan penurunan kemampuan mempertahankan keseimbangan postural atau keseimbangan tubuh lansia. Perlu dilakukan penelitian lanjutan terkait postur tubuh terhadap gangguan yang dialami lansia. Penelitian ini bertujuan untuk mengetahui hubungan antara postur kifosis dengan gangguan keseimbangan statis pada lansia di posyandu wilayah Semaka.

\section{METODE PENELITIAN}

Penelitian ini menggunakan jenis penelitian kuantitatif dengan deskriptif korelasi. Metode pendekatan waktu yang akan digunakan dalam penelitian ini adalah cross sectional. Metode yang digunakan dalam pengambilan sampel yaitu teknik purposive sampling. Populasi pada penelitian ini adalah seluruh lanjut usia umur 60-80 tahun yang berjumlah sebanyak 174 lansia di posyandu wilayah Semaka.

Sampel dalam penelitian ini sejumlah 60 lansia yang mau melakukan penelitian dengan suka rela. Pengumpulan data pada penelitian ini diawali dengan pengumpulan responden setelah itu responden diminta untuk mengisi informad concent. Kemudian dilakukan pemilihan responden sesuai kreteria inklusi ( perempuan dan laki-laki usia 6080 tahun, bersedia menjadi responden, dapat berkomunikasi dengan baik, responden yang tidak mengalami pusing) dan eksklusi (memiliki cedera, pasca operasi fraktur ekstremitas atas dan bawah, menggunakan alat bantu gerak), lalu dilakukan penilaian keseimbangan statis dan penilaian postur kifosis. Jika semua data sudah terkumpul selanjutnya akan dilakukan pengolahan data berupa editing, coding, data entry, tabulating. Uji analisis dilakukan dengan uji Kendal-tau, menggunakan SPSS. 
HASIL PENELITIAN

Tabel 1. Karakteristik Responden

\begin{tabular}{|c|c|}
\hline & $(\%)$ \\
\hline \multicolumn{2}{|l|}{ Jenis Kelamin } \\
\hline - Laki - laki & 58,3 \\
\hline - Perempuan & 41,7 \\
\hline \multicolumn{2}{|l|}{ Umur } \\
\hline - 60-65 & 41,7 \\
\hline$-66-70$ & 26,7 \\
\hline$-71-75$ & 11,7 \\
\hline - 76-80 & 20,0 \\
\hline \multicolumn{2}{|l|}{ IMT } \\
\hline - Underweight & 20,0 \\
\hline - Normal & 66,7 \\
\hline - Overweight & 10,0 \\
\hline - Obese & 3,3 \\
\hline \multicolumn{2}{|l|}{ Postur } \\
\hline - Kifosis & 31,7 \\
\hline - Tidak Kifosis & 64,3 \\
\hline \multicolumn{2}{|l|}{ Keseimbangan } \\
\hline - Buruk & 65,5 \\
\hline - Baik & 30,0 \\
\hline - Sangat baik & 5,0 \\
\hline Total & 100.0 \\
\hline $\begin{array}{l}\text { Dilihat dari tabel } 1 \text { dapat } \\
\text { disimpulkan bahwa dari } 60 \text { sampel, } \\
\text { dengan jumlah terbanyak jenis } \\
\text { laki-laki dengan jumlah } 35 \text { sampel } \\
(58.3 \%) \text {. Usia } 60 \text { sampel, dengan jumlah } \\
\text { terbanyak pada umur } 60-65 \text { sebanyak } 25 \\
\text { sampel dengan presentase } 41.7 \% \text {, } \\
\text { jumlah umur tersedikit pada umur } 71-75 \\
\text { sebanyak } 7 \text { sampel dengan presentase } \\
11.7 \% \text {. Untuk IMT kategori terbanyak } \\
\text { yaitu kategori IMT normal dengan } 40 \\
\text { sampel (66.7\%) dan jumlah tersedikit } \\
\text { dengan kategori obese dengan } 2 \text { sampel } \\
(3.3 \%) \text {. }\end{array}$ & $\begin{array}{l}\text { Dilihat dari tabel } \\
\text { disimpulkan bahwa dari } 60 \text { sampel, } \\
\text { dengan jumlah terbanyak } \\
\text { dengan } \\
\text { kategori postur tidak kifosis dengan } 41 \\
\text { sampel }(64.3 \%) \text {. Untuk kategori } \\
\text { keseimbangan dari } 60 \text { sampel jumlah } \\
\text { terbayak dengan kategori keseimbangan } \\
\text { buruk sebanyak } 39 \text { sampel }(65.0 \%) \text {. Uji } \\
\text { normal dari uji Kolmogorov-Smirnov } \\
\text { didapatkan hasil test berdasarkan hasil } \\
\text { test terdapat data terdistribusi tidak } \\
\text { normal dengan postur p value }(0,001)< \\
\text { a }(0,05) \text {, keseimbangan }(0,001)<\text { a } \\
(0,05) \text {. }\end{array}$ \\
\hline
\end{tabular}

Tabel 2. Hubungan Postur Kifosis Dengan Gangguan Keseimbangan Statis

\begin{tabular}{ccc}
\hline \multirow{2}{*}{ Keseimbangan } & \multicolumn{2}{c}{ Postur } \\
\cline { 2 - 3 } & $P$ Value & Korelasi \\
\cline { 2 - 3 } & 0,389 & 0.000 \\
\hline
\end{tabular}


Berdasarkan tabel 2 dapat diketahui bahwa dari hasil uji kendall tau diperoleh nilai hitung postur 0,001 dengan nilai signifikan 0,389 . Hal ini menunjukkan bahwa nilai $p<0,05$, maka Ha diterima dan Ho ditolak, terdapat hubungan antara postur kifosis dan gangguan keseimbangan statis pada lansia. Nilai koefisien kolerasi sebesar 0,001 pada uji ini tingkat hubungan menunjukkan bahwa hubungan tersebut kuat.

\section{PEMBAHASAN}

Pada penelitian ini sampel menurut jenis kelamin dari 60 sampel terbagi menjadi dua kelompok yaitu laki-laki dan perempuan. Jenis kelamin laki-laki lebih banyak mengalami gangguan keseimbangan. Menurut penelitian yang dilakukan (Sulaiman \& Anggriani, 2018) lanjut usia berjenis kelamin laki-laki juga dapat mengalami gangguan keseimbangan lebih buruk dari pada lansia berjenis kelamin perempuan disebabkan karena pada usia mudanya atau usia produktif melakukan pekerjaan dengan kapasitas tinggi seperti mengangkat benda-benda yang sangat berat yang menyebabkan menjelang usia lanjut terjadi keseimbangan yang buruk, ditambah lagi kurangnya lanjut usia memeriksa kesehatan terutama kesehatan dasar disarana kesehatan yang telah disediakan pemerintah melalui posyandu dan puskesmas.

Pada penelitian ini umur lansia dikelompokan menjadi 4 kelompok yaitu umur 60-65, umur 61-70, umur 71-75, umur 76-80, dan didapatkan hasil bahwa tidak hanya umur lansia tua saja yang mengalami gangguan keseimbangan tetapi lansia awalpun banyak yang mengalami gangguan keseimbangan.
Menurut penelitian yang dilakukan (Wijaya, 2019) lansia dengan usia >60 tahun yang bisa menjaga kebugaran fisik dengan baik maka akan memperlambat proses degeneratif. Akan tetapi, fakta yang ditemukan di masyarakat masih banyak lansia yang mengalami kemunduran fisik karena tidak menjaga kebugaran fisik.

Menurut (Pristianto et al., 2016) olahraga yang teratur dan terprogram maka kebugaran tubuh akan lebih baik lagi, kemampuan otot akan lebih optimal bergerak dan saat menopang tubuh sehingga koordinasipun menjadi lebih seimbang. Menurut (Pangkahila, 2013) mengatur pola hidup meliputi pola tidur, makan, olahraga/bergerak, bekerja, dan tidak stress. Pola hidup menentukan proses penuaan dan pola hidup ini menyesuaikan kondisi lansia, hingga lansia sendiri harus menentukan pola hidup sehat untuk dirinya sendiri. Pada saat seseorang melakukan sesuatu aktivitas dimana beban kerja melampaui kapasitas kerja maka saat itu mulai terjadi radikal bebas disamping penurunan beberapa kadar hormon sehingga keadaan inilah yang akan mempercepat proses penuaan.

Pada penelitian ini IMT dikelompokan menjadi 4 yaitu underweigh, normal, Overwight, obese. Didapatkan hasil bahwa IMT normal lebih banyak mengalami gangguan keseimbangan. Menurut (Suparwati, Paramurthi, \& Prianthara, 2017), keseimbangan dipengaruhi beberapa faktor seperti motivasi, kognisi, lingkungan, kelelahan, kesungguhan melakukan test dan lainnya. Tak kalah penting aktivitas fisik juga berpengaruh pada keseimbangan dan membuat lansia tetap aktif serta memperdayakan lansia 
agar tetap sehat. Menurut (Setiawan \& Setiowati, 2014), seseorang yang rajin melakukan olahraga dapat berpengaruh pada peningkatan kekuatan otot dan sebaliknya jika jarang olahraga mampu menurutkan kekutan otot, seseorang yang memiliki kekuatan otot yang baik maka memiliki keseimbangan yang baik. Sehingga dalam penelitian ini dapat disimpulkan bahwa IMT belum cukup mempengaruhi gangguan keseimbangan seseorang.

Hasil penelitian menunjukkan adanya hubungan antara postur kifosis dan gangguan keseimbangan statis lansia. Menurut penelitian yang dilakukan (Prasetya, Wibawa, \& Putra, 2014) menyatakan bahwa ada hubungan yang signifikan postur tubuh terhadap keseimbangan statis pada lansia. Dalam melakukan aktivitas kehidupan seharihari (AKS) seseorang terlebih dahulu akan melakukan gerakan statik. Gerakan statis adalah sesuatu hal yang sangat berat, karena segmen pada setiap manusia memiliki kemampuan dan derajat kebebasan gerak sangat berbedabeda pada lansia sehingga postur tubuh berperan sangat penting dalam menjaga keseimbangan. Postur yang berubah membungkuk akan menyebabkan pergeseran pusat gravitasi (COG) dan kelemahan atau kelelahan otot corestability berakibat pada penurunan stabilitas statis batang tubuh, dengan demikian menyebabkan hilangnya kontrol keseimbangan (Ivanenko \& Gurfinkel, 2018).

Menurut penelitian yang dilakukan oleh (Navega, Furlanetto, Lorenzo, Morcelli, \& Tozim, 2016) diketahui bahwa program pilates efektif menurunkan tingkat thoracic hyperkyphosis sehingga memelihara keseimbangan lansia, dari penelitian tersebut bahwa dapat disimpulkan adanya hubungan antara penurunan thoracic hyperkyphosis terhadap peningkatan keseimbangan lansia. Hasil ini didukung pula oleh penelitian (Jang, Hughes, Oh, \& Kim, 2019) yang menunjukan bahwa program latihan yang ditujukan kepada lansia yang memiliki postur hiperkifosis menjadi efektif dan efesien dimana secara positif mempengaruhi perubahan postural statis dan dinamis sehingga meningkatkan postur, keseimbangan, dan kesejahteraan bagi lansia itu sendiri.

\section{KESIMPULAN DAN SARAN}

Adanya
perubahan
postur $\begin{array}{r}\text { antara } \\ \text { terhadap }\end{array}$ keseimbangan statis lansia di posyandu wilayah Semaka. Responden yang mengalami kifosis yaitu sebanyak $31,7 \%$, serta yang mengalami gangguan keseimbangan buruk sebanyak 39 sampel atau $65,0 \%$.

Petugas kesehatan dapat melaksanakan penyuluhan secara rutin tentang pencegahan resiko jatuh dengan memperbaiki gangguan keseimbangan pada lansia guna meningkatkan upaya preventif. Pemegang kebijakan diharapkan menyediakan tempat posbindu yang layak dan nyaman untuk masyarakatnya. Selain itu perlu adanya fasilitas umum yang aman bagi lansia.

\section{DAFTAR RUJUKAN}

Ibrahim, F. A., Nurhasanah, \& Juanita2. (2018). Hubungan Keseimbangan Dengan Aktivitas Sehari-Hari Pada Lansia Di Puskesmas Aceh Besar. Idea Nursing Journal, IX(2), 7-13.

Ivanenko, Y., \& Gurfinkel, V. S. (2018). 
Human postural control. Frontiers in Neuroscience, 12(MAR), 1-9. https://doi.org/10.3389/fnins.2018. 00171

Jang, H. J., Hughes, L. C., Oh, D. W., \& Kim, S. Y. (2019). Effects of Corrective Exercise for Thoracic Hyperkyphosis on Posture, Balance, and Well-Being in Older Women: A Double-Blind, GroupMatched Design. Journal of Geriatric Physical Therapy (2001), 42(3), E17-E27. https://doi.org/10.1519/JPT.00000 00000000146

Navega, M. T., Furlanetto, M. G., Lorenzo, D. M., Morcelli, M. H., \& Tozim, B. M. (2016). Effect of the Mat Pilates method on postural balance and thoracic hyperkyphosis among elderly women: a randomized controlled trial. Revista Brasileira de Griatria e Gerontologia, 19(3), 465-472. https://doi.org/https://doi.org/10.15 90/1809-98232016019.150022

Nuraini, K., Haryanto, J., \& Fauzingtyas, R. (2017). Analisis Faktor Determinan Penyebab Jatuh pada Lansia dengan Diabetes Mellitus di Wilayah Kerja Puskesmas Bantul 1 Yogyakarta. Jurnal Keperawatan Respati Yogyakarta, 4(2), 171178.

Pangkahila, J. A. (2013). Pengaturan Pola Hidup Dan Aktifitas Fisik Meningkatkan Umur Harapan Hidup. Sport and Fitness Journa, 1(1), 1-11. Retrieved from https://ojs.unud.ac.id/index.php/sp ort/article/view/6062/4556

Pramadita, A. P., Wati, A. P., Muhartomo, H., Kognitif, F., \& Romberg, T. (2019). Hubungan Fungsi Kognitif Dengan Gangguan Keseimbangan Postural Pada Lansia. Jurnal Kedokteran Diponegoro, 8(2), 626-641. Retrieved from https://ejournal3.undip.ac.id/index. php/medico/article/view/23782

Prasetya, L. Y., Wibawa, A., \& Putra, I. N. A. (2014). Hubungan antara postur tubuh terhadap keseimbangan static pada lansia. Skripsi, Jurusan Fisioterapi Fakultas Kedokteran Universitas Udayana Denpasar Bali.

Pristianto, A., Adiputra, N., \& Irfan, M. (2016). Perbandingan Kombinasi Bergantian Senam Lansia Dan Latihan Core Stability Dengan Hanya Senam Lansia Terhadap Peningkatan Keseimbangan Statis Lansia. Sport and Fitness Journal, 4(1), 1-15. Retrieved from https://ojs.unud.ac.id/index.php/sp ort/article/view/20198/13398

Rudy, A., \& Setyanto, R. B. (2019). Analisis Faktor yang mempengaruhi Resiko Jatuh pada Lansia. Jurnal Ilmiah Ilmu Kesehatan, 5(2), 162-166. Retrieved from https://www.researchgate.net/publi cation/330841101_Analisis_Faktor _Yang_Mempengaruhi_Risiko_Jat uh_Pada_Lansia

Sari, M. K. (2016). Peningkatan kualitas 
hidup lansia menggunakan. 81 Maret, 4(1), 81-90.

Setiawan, D. A., \& Setiowati, A. (2014). Hubungan Indeks Massa Tubuh (Imt) Terhadap Kekuatan Otot Pada Lansia Di Panti Wredha Rindang Asih Iii Kecamatan Boja. JSSF (Journal of Sport Science and Fitness), 3(3), 30-35. Retrieved from https://journal.unnes.ac.id/sju/inde x.php/jssf/article/view/6254

Sulaiman, \& Anggriani. (2018). Efek Postur Tubuh Terhadap Keseimbangan Lanjut Usia Di Desa Suka Raya Kecamatan Pancur Batu. Jurnal JUMANTIK, 3(2), 127-140. Retrieved from http://jurnal.uinsu.ac.id/index.php/ kesmas/article/view/2875/1714

Suparwati, K. T. A., Paramurthi, I. A. P., \& Prianthara, I. M. D. (2017). Senam Aerobic Low Impact Dapat Meningkatkan Di Siswa Plaza Kota Denpasar. 1(November), 19. Retrieved from http://ejournal.unbi.ac.id/index.php /BHJ/article/view/6/6

Wijaya, N. K. (2019). Hubungan Karakteristik Individu, Aktivitas Fisik dan Gaya Hidup dengan Tingkat Kebugaran Fisik Pada Lansia, Skripsi. Program Studi S1 Keperawatan Fakultas Keperawatan Universitas Airlangga Surabaya. 